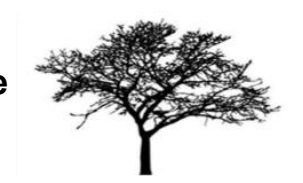

\title{
NATURE IN CLASSICAL JAPANESE LITERATURE - AN ECOCRITICAL PERSPECTIVE OF THE PLANTS IN THE DIARY OF LADY MURASAKI
}

\section{Dr. Esin ESEN*}

\begin{abstract}
This study endeavors to answer how nature is represented in a classical Japanese text, the diary of Lady Murasaki with an ecocritical perspective with respect to plants focusing on the subject with a secondary nature phoneme. To answer this question, a complete list of the plants in the diary was set forth in the first section, which is a first in the field. While doing this, Lady Murasaki's perception of plants was given the central position and a taxonomy for the plants appearing in the diary was suggested by utilizing the words used by Murasaki herself in the text, which made it possible to include the entries not associated with seasons. As a result of the findings in this first part of the article, it was identified that the plants in the text represent the secondary nature. In the second part of the article, the text was analyzed for the forms the secondary nature took in the diary. In the analysis, results showing associations of plant references with particular locations and seasons were reached. This study is the first on this subject to discuss nature in The Diary of Lady Murasaki with respect to plants with an ecocritical approach in Japan, Turkey and the world.
\end{abstract}

Keywords: Classical Japanese Literature, plants, Murasaki Shikibu, ecocritism, secondary nature

KLASIK JAPON EDEBIYATINDA DOĞA- MURASAKI SHIKIBU'NUN GÜNLÜĞÜ'NDEKI BITKILERE EKOELEŞTIREL BAKIŞ

\section{öz}

Bu çalışmada bir klasik Japon edebiyatı metni olan Murasaki Shikibu'nun Günlüğünde doğanın nasıl temsil edildiği sorusunun cevabı, ekoeleştirel yaklaşımla, metinde yer alan bitkiler ikincil doğa kavramı üzerinden incelenerek araştırılmıştır. Bu amaçla ilk bölümde klasik Japonca metin analiz edilerek, günlükte yer alan tüm bitkilerin listesi oluşturulmuştur. Bu liste bu konuda Japonya da dahil dünyada ilk çalışmadır. Metinde tespit edilen bitkiler, yazarın algısına odaklanarak onun sözcükleriyle sınıflandırımıştır. Bu, mevsimlerle ilintili olmayan girdilerin de sınıflandırılmasına olanak vermiştir. İlk bölümde elde edilen sonuçlara göre metinde sadece ikincil doğanın temsil edildiği ortaya konulmuştur. Sonraki bölümde, ikincil doğanın, hangi formlarda metinde yer aldığı ortaya konmuştur. Bu formlar yer ve mevsim ilişkisi üzerinden incelenerek sonuçlara ulaşılmıştır. Bu çalışma Japonya, Türkiye ve dünyada, Murasaki Shikibu'nun Günlügünü, bitkiler açısından ekoeleştirel yaklaşımla ele alan ilk çalışmadır.

Anahtar Kelimeler: Klasik Japon edebiyatı, bitkiler, Murasaki Shikibu, ekoeleştiri, ikincil doğa

\section{Introduction}

\footnotetext{
*Asya Çalışmaları Merkezi- araştırmacı. esinesenacademia@gmail.com, Orcıd ID: 0000-00028348-9125
} 
Classical Japanese literature and especially the Heian Period women's literature are deeply associated with nature. Nature takes place in poems, tales, or diaries abundantly and in various aspects. The author identifies himself/herself with nature, records meticulously the circle of the seasons which he/she understands as the circle of life, and seasonal changes reflected in daily lives of the people which can be traced through texts and so on. So, in the research of classical Japanese literature, nature deserves special attention in order to obtain a deeper understanding of the texts.

Ecocritcism provides an important point of view to analyze literary works in terms of nature, which is "the study of the relationship between literature and physical environment (Glotfelty and Fromm, 1996: xviii)" Although ecocritism's main concern is art in terms of ecology and environmental aspects (Zapf, 2016 ) it also deals with people's understanding of nature, the ways in which literature represents the human relation to nature at particular points in history etc. (Heise, 2006: 1097; Shirane, 2012: xiii). This study deals with the diary of one of the most prominent writers of classical Japanese literature of the Heian Period, Murasaki Shikibu, with an ecocritical look.

Murasaki Shikibu is well known for her novel The Tale of Genji [Genji Monogatari]. She wrote her diary between the years 1008-1010, while she was a ladyin-waiting in the royal court, describing both the events at court and her personal life. The diary consists of three volumes. The first volume shares the events of the birth of the first prince. The second volume is the epistolary volume, related to the author's personal world, her memories, and her descriptions of the ladies-in-waiting at the court of the Empress. The last volume shares Murasaki Shikibu's memories of court life and of the ceremonies surrounding the birth of the second prince.

A close examination of the nature related aspects of the diary reveals that the plants play a core role in the text. With this in mind, the research topic has been narrowed down to "the plants in The Diary of Lady Murasak" in order to obtain more coherent results. In keeping with this decision, the primary focus of the article has been to address nature [plants] with an ecocritical perspective, because in Japanese art and literature nature is represented not "in its original state but its idealized state" (Asquith and Kalland 1997: 16 cited by Masami 2017: 4). The research conducted on ecocritism and nature in Japanese literature led to Shirane's 'secondary nature [nijiteki shizen]', which provides deep insights to understand nature in classical Japanese literature.

Shirane divides nature into primary and secondary natures. He does not define the primary nature but from his text we can grasp that primary nature is the "nature's original state" (Asquith and Kalland, 1997: 16) or the nature outside the cities. Where as he defines the secondary nature "re-created or represented nature" by human beings (Shirane, 2012: 2-4). He does not see secondary nature as opposed to the human world, but rather as an extension of it (Shirane, 2012 2-4). According to him, nature "reconstructed in gardens or visually and textually depicted in paintings, furniture, dress, poetry, and illustrated tales" are examples of the secondary nature (Shirane, 2012: 2-4). He explains "secondary nature" has emerged in art when people moved into the cities, as early as the seventh century (Shirane, 2012: 18). After that, secondary nature "became a substitute for a more primary nature that was often remote from or rarely seen by aristocrats who lived in [...]" the cities, (Shirane, 2012: 2- 
$4,18)$ "and became a surrogate for more primary nature for urban inhabitants" (2012: 18). Shirane states that secondary nature influenced almost every major cultural form in the premodern period in Japan (Shirane, 2012: 18). The "secondary nature took many forms and appeared in such diverse genres as poetry, screen paintings, gardens, flower arrangement, and the tea ceremony" (Shirane, 2012: 18).

Glotfelty and Fromm (1996: xviii, xix) notes some questions that ecocritics may deal with, in their studies, which indicate an important trajectory for the researchers, focusing on different aspects of relations between nature and literature (Glotfelty and Fromm, 1996: xviii, xix). The first of these questions is "how nature is represented" in a literary work. This study will also examine the same question for the diary of the Lady Murasaki, with respect to plants. To identify this, the following questions will be asked: What is represented of nature in terms of plants? Does the text represent primary or secondary nature? What forms do the secondary nature take in the text with respect to plants, is it a material, or a tree in the garden, or has it appeared in a poem in the text? What is the association of the places with the forms of secondary nature? What is the association of the seasons and time with the secondary nature?

The main source for the analysis in this article is the Murasaki Shikibu Nikki Kurokawa-bon Copy (Shikibu, 1970, 2008), the digital version of the text has been accessed from the link below ${ }^{1}$. Modern Japanese (Shikibu, 2008), English (Shikibu, 1996) and Turkish (Shikibu, 2009) translations have also been consulted.

In the previous studies of Japanese literature with the view point of ecocritisim, Shirane's work "Japan and the Culture of the Four Seasons: Nature, Literature, and the Arts (2012)" have been an important source. The book titled "Ecocritism in Japan" edited by Wake et.al (2017) covers a wide range of Japanese literary history from the early ages to recent times on this subject. Rhine (2017) with her essay on The Tale of Genji by Murasaki Shikibu in the same book, forms a ground for analyzing the Heian texts with an ecocritical perspective, which is also based on Shirane's "secondary nature" concept. On the other hand in Turkey, where the author of this article conducts research on Japanese Studies, there are studies on ecocritism (Arıkan, 2011; Ergin and Dolcerocca, 2016; Sazyek and Sürücü 2018 etc.), although most of them are related to environmental subjects. There is no study dealing with Japanese literature with ecocritical approach in Turkey. In Japan, there are studies on ecocritism [エコクリティシズム] or secondary nature (Noda, 2011; Katō, 2011 etc.). However, there are no researches on the diary of Lady Murasaki focusing on the book with an ecocritical approach or dealing with the subject from the point of view of secondary nature. Focusing on the plants or nature in The Diary of Lady Murasaki a search of electronic sources, databases and the catalog of the National Diet Library of Japan shows that there has been no previous research on the whole plants in the diary. The author of this paper has a presentation dating to 2012 which is dealt with the plants in the diary partially. Of the more than 300 entries on the diary listed in $\mathrm{Cinii}^{2}$, there are

\footnotetext{
${ }^{1}$ Digital text of MSN Kurokawa-bon copy: http://www.sainet.or.jp/ eshibuya/original55.html (accessed: 2012- 2019).

2 http://ci.nii.ac.jp/search?q=\%E7\%B4\%AB\%E5\%BC\%8F\%E9\%83\%A8\%E6\%97\%A5\%E8\%A8 $\% 98 \&$ range $=0 \&$ count $=20 \&$ sortorder $=1$ \&type $=0$ (accessed between: $8.2012 / 1.2019$ ).
} 
only a few studies on specific flowers, such as on the poetic treatment of the maiden flower (Takeuchi, 1983) and the Ume no Hana poem of Saemon no Naishi (Inaga, 1971), and a study on gardens of the period (Kawahara, 1987) which includes the diary. By means of contrast, there are a great number of academic studies, books and web pages about the plants in The Tale of Genji, the famous novel by Murasaki Shikibu, and about the plants of the Heian capital (Fujimoto, 1971; Hiroe, 1969; Hiroe, 1981; Hirokawa, 1978; Koga, 1971; Matsuda, 1980; Ōnuki, 1986; Toyama, 1927 and others). This study will be a first step to discuss The Diary of the Lady Murasaki in terms of nature and plants, with an ecocritical approach in Japan, in Turkey and in the world.

\section{of Plants?}

2. What is Represented as Nature in the Diary of Lady Murasaki in Terms

\subsection{Complete List of the Plants of the Diary and an Attempt to a Taxonomy}

Shirane suggests that "a fundamental grasp of The Tale of Genji" the book written by Lady Murasaki "requires an understanding of the literary implications of a wide variety of plants, flowers, atmospheric conditions and [...] not only the names of the characters but also the settings in which they appear (Shirane, 2012: 1)" The same suggestion is valid for The Diary of Lady Murasaki. With this in mind, first the whole text was analyzed in terms of plants by detailed scanning of the original Kurokawa-bon copy. As a result of long and meticulous reading of the diary, all the plants appearing in the text were set forth. Please find in the appendix, with the complete list of the plants in The Diary of Lady Murasaki. Each entry was listed in their order of appearance in the text. The classical Japanese text was cited with explanatory glosses in English. Only plants that are referred to explicitly in the diary have been incorporated into the analysis.

After obtaining the above mentioned data, the next challenge was to determine how to classify the plants in the diary. In studies on plants in classical Japanese literature, the traditional manner of categorizing plants has been based on seasons. This approach is based on Classical Japanese poetry anthologies after Kokinshū (Keene 1999: 251). Another manner of categorizing plants has been to use a scientific taxonomy. (Niwa and Muramoto 1937). However, these approaches are not appropriate for this study because there are entries unrelated to seasons or a scientific taxonomy and therefore, they would be irrelevant. So, with the point of view of ecocritism in mind, the text examined with the intention to uncover Lady Murasaki's view of plants. After this detailed analysis of the text and analyzing the entries listed in the appendix, it became clear that, as Murasaki's words indicate, in her conception the plants were simply divided into $K i$ [Tree] (Shikibu 2008: 123, 124, 142, 158, 169), Hana [Flower] (Shikibu 2008: 129, 169, 194), and Kusa [Herb or Grass] (Shikibu 2008: 123, 140) ${ }^{3}$.

In view of this, I would like to suggest a taxonomy that consists of the three headings indicates the words used by Lady Murasaki herself to refer plants, together with another more pragmatic category. In this fourth "Other" category, it can be placed the entries that Murasaki did not verbalize to point out any plant class in the diary, and

\footnotetext{
${ }^{3}$ All citations to (Shikibu 2008) are given only with page numbers in this paper.
} 
that do not seem to fit in any another coherent class ${ }^{4}$. Among these four categories, one category Hana [flower], can be further sub-divided into the categorizations of 'flowers growing on bushes or on the land' and 'blossoms on trees'. And these subcategorizations are better grasped from the translations of the diary than the original in Japanese. In the time of Lady Murasaki, moreover, some flowers were considered as kusa [herb], which could serve as another sub-categorization, but it is not utilized in this study as there is insufficient textual evidence in the diary or its translations to prove that Lady Murasaki's conceptualization of plants included a notion of kusa-hana [herbflower]. Therefore, in this study the following categorizations are used for the plants: 1)Kusa 草 [Herb or grass] 2) Hana 花 [Flower] a)Hana [Flower] b)Ki no Hana [Blossoms] 3) $K i$ 木 [Tree] 4) Other.

Applying the above-mentioned classification method to the plants seen in the diary (Please see appendix), the following breakdown of the plants emerges:

In total, 24 different words are used when mentioning a plant, 84 times (please see appendix for complete list). 4 of them are general terms such as tree, grass, etc., which appear 16 times in the text. The remaining 20 are the names of specific plants, which have been used a total of 68 times in the text. Table 1 represents the plants that appear in the diary of Lady Murasaki.

\begin{tabular}{|c|c|c|c|c|}
\hline \multirow[t]{2}{*}{ Kusa 草/ Herb or Grass } & \multicolumn{2}{|c|}{ Hana花/ Flower } & \multirow[t]{2}{*}{$K i$ 木/ Tree } & \multirow[t]{2}{*}{ Other } \\
\hline & Hana-Flower & Ki no Hana-Blossoms & & \\
\hline $\begin{array}{l}\text { 1) Kusamura草むら: Tuft of the grass } \\
\text { 2) Aki no kusamura 秋の草叴ら: Autumn } \\
\text { herbs (1) }\end{array}$ & \multicolumn{2}{|l|}{ 5) Hana花: Flower } & $\begin{array}{l}\text { 16) } K i \text { 木: Tree and } \\
\text { branch, leaves }\end{array}$ & \\
\hline 3) Karakusa 唐草: Chinese-vine & 6) Fuji 藤: Wisteria & 13) Ume 梅Plum & 17) Matsu松: Pine & \multirow[t]{2}{*}{ 22) Tsuta蔦: Vine } \\
\hline \multirow[t]{6}{*}{ 4) Ukikusa 浮き草: Duckweed } & $\begin{array}{l}\text { 7) Ominaeshi女郎 } \\
\text { 花:Maiden-flower }\end{array}$ & $\begin{array}{l}\text { 14) Sakura 桜: } \\
\text { Cherry }\end{array}$ & $\begin{array}{l}\text { 18) Chin 沈: Aloes- } \\
\text { wood }\end{array}$ & \\
\hline & $\begin{array}{l}\text { 8) Hagi 萩:Japanese-bush- } \\
\text { clover }\end{array}$ & $\begin{array}{l}\text { 15) Suō 蘇芳: } \\
\text { Sappan-wood }\end{array}$ & $\begin{array}{l}\text { 19) Maki } \\
\text { 槙:Japanese-cedar }\end{array}$ & 23) (Ebi) 葡萄: Grape \\
\hline & 9) Shion紫苑:Aster & & \multirow{2}{*}{$\begin{array}{l}\text { 20) Yanagi柳: } \\
\text { Willow }\end{array}$} & \multirow[t]{4}{*}{ 24) Ashi 莘: Reed } \\
\hline & $\begin{array}{l}\text { 10) Kiku 菊: } \\
\text { Chrysanthemum }\end{array}$ & & & \\
\hline & $\begin{array}{l}\text { 11) Kuchinashi柧子: } \\
\text { Gardenia }\end{array}$ & & \multirow[t]{2}{*}{$\begin{array}{l}\text { 21) Ume 梅Plum } \\
\text { fruit }\end{array}$} & \\
\hline & $\begin{array}{l}\text { 12) Yamabuki 山吹:Japanese } \\
\text { rose }\end{array}$ & & & \\
\hline \multicolumn{5}{|c|}{ TOTAL: $\quad 24$ (used 84 times) } \\
\hline \multirow{2}{*}{$\begin{array}{l}\text { General Definitions: } \\
\text { Names of plants: }\end{array}$} & 4 & (used $15+1$ times) & & \\
\hline & 20 & (used 68 times) & & \\
\hline
\end{tabular}

Table 1 - Plants in the Diary of Lady Murasaki and a Taxonomy

\subsection{Do the Plants in the Diary Represent Primary or Secondary Nature?}

As stated above, Shirane in his study speaks of two types of natures. One is primary, which is the nature outside the cities, remote from or rarely seen by aristocrats (Shirane, 2012: 2-4, 18). We can call it as "nature's original state" (Asquith and Kalland,

\footnotetext{
${ }^{4}$ This category can be changed with further studies on her novel, by scanning the words she used to refer specific plants.
} 
1997: 16). The other is the secondary nature, which he describes as re-created or represented nature in the cities by aristocrats (Shirane, 2012: 2-4). From this view point, I first focused on the sites, which took place in the texture of the diary, in order to find out if they are within the cities or remote from the cities.

Tree main sites are depicted in the diary. The primary site described is the Tsuchimikado Mansion. This was the residence of the father of the Empress Shōshi, regent Michinaga, during the time of his unrivalled power (Coaldrake, 2002: 91). It was to here that the Empress "came to give birth. Partly this was to avoid the strict taboo on the shedding of blood in the precincts of the Imperial Palace" (Bowring, 1996: xxv). The next most described site in the diary is the Ichijo Palace, Imperial Palace where the Empress returned after marking the $50^{\text {th }}$ day anniversary of the prince's birth. It was close to the Tsuchimikado Mansion, (Coaldrake, 2002: 89). In addition, there are some fragmentary descriptions of Murasaki Shikibu's own house. These show us that 1) All of these sites are in cities 2) All these three places are shinden-zukuri [寝殿造] buildings which were aristocratic mansions of the Heian Period. These two data indicate that, these places are related to secondary nature.

Then, 84 entries related to plants in the diary were examined. The results showed that none of them represented nature in its original state, namely primary nature. All entries represent 'recreated nature' (See appendix).

From the data mentioned above, it can be concluded that the diary does not represent primary nature. On the contrary, all the entries reflect the nature within the walls of shinden-zukuri mansions, which Shirane speaks for as a part of recreated nature, namely secondary nature.

\section{Secondary Nature and Its Forms in the Diary with Respect to Plants}

Shirane describes the nature, as pervasive both spatially and psychologically, in the lives of noble women of the Heian Period (2012: 15) and re-created as secondary nature. This secondary nature was "carefully reconstructed" in different art forms to build"an ideal environment through linguistic, visual, tactile, and alimentary means" (Shirane, 2012: 15). He explains that the forms of secondary nature took form as follows in the Heian Period women's literature:

"[...] for the most part the only nature that such women encountered was in the gardens of their [...] shinden-zukuri residences; [and also the nature which] was represented extensively indoors, in picture scrolls (emaki-mono), screen paintings (byōbu-e) and door or partition paintings (fusuma-e), and permeated the waka that they wrote that day and night." (Shirane, 2012: 2).

From this point of view, the plants belonging to the four categories set forth in the previous title were searched through the text in order to determine the forms appearing as secondary nature in the diary. As a result, the four previously mentioned titles were developed, by adding the forms which are listed below. Each of these forms has been analyzed according to the three locations that the diary entries depict and 
according the seasons of the entries ${ }^{5}$.

\subsection{The Shinden-zukuri Mansions}

Shinden-zukuri was the architectural style of the mansions of small elite group, no more than a few thousand people, in Heian Period (Coaldrake, 2002: 83). Shindenzukuri mansions shared a common style with variations according to the rank of their owners (Coaldrake, 2002: 83, 88) which can be Imperial Palaces, Clan Centers for the powerful members of the court or individual mansions of aristocrats (Coaldrake, 2002: 83).

\section{The Shinden-zukuri Mansion- Garden}

Shinden-zukuri mansions had large gardens, which were a miniaturized representation of nature at large. These gardens most often consisted of small mounds representing hills or mountains, and ponds representing lake or other bodies of water. These ponds frequently had a small island in the middle with pine trees (Armstrong, 2001: 4-5, Esen, 2009 xxxvii-xliv, Goshima, 1998: 12-15, Shirane, 2012: 89). The design of the gardens of these mansions might have varied, but again had rules to shape them:

"In the shinden-zukuri garden there is a large pond laid out in front of the main building, facing the sunny south where plants thrive best with plenty of light and warmth. [...] a highly curved bridge was spanned from the north side of the island, and a flat bridge from the opposite side. [...] At each side of the pond stood a pavilion facing the pond. [...] Between the intervals of various buildings ran a narrow stream, forming here and there a pretty landscape scene with flowers and tiny plants transplanted from mountains or plains. (Tsuda, 2009: 192)"

The main point of the architectural style of these mansions was to have "most of the interior spaces to open directly onto the garden [...] integrating the interior with the exterior" (Shirane, 2012: 90). There were, however some fixed walls separating the exterior from the interior "allowing garden and sense of nature flow inside to the world of private preoccupation of the aristocrats (Coaldrake, 2002: 90)." This feature of the shinden-zukuri mansions allowed Lady Murasaki to record the gardens, contemplating the garden, while being inside the buildings. This is the main feature of all entries related to garden in the diary as can be seen below:

Tsuchimikado Mansion: There are several entries depicting the Tsuchimikado Mansion's garden. The four categories in above mentioned taxonomy take place in these depictions. 1) For kusa category there is one entry. Lady Murasaki depicts the autumn scene of Tsuchimikado Mansion garden in the opening passage of the text, also mentioning the grass [kusa] in the garden (123). 2) For hana category there are two flowers depicted in the Tsuchimikado Mansion's garden. Both are flowers associated with autumn, but in the text kiku [chrysanthemums] appears in the winter entry of the diary. Lady Murasaki describes the ominaeshi [maiden-flowers/ yellow

\footnotetext{
${ }^{5}$ The diary entries fall roughly into following periods, with some time lapses: Autumn 1008, Winter 1008, Spring 1009 and Spring 1010.
} 
valerian $]^{6}(125)$ in the garden of Tsuchimikado Mansion, at the time she is exchanging poems with Michinaga. The depiction of kiku [chrysanthemums] varying colors takes place in the diary, which were transplanted for the imperial visit and arranged in various ways (150). Socio-culturally, the chrysanthemum is associated with the royal family and is the symbol of the Japanese emperor. It has this symbolism for its resemblance to the sun. In Japanese mythology the sun goddess Amaterasu is the ancestor of the first Emperor [Jinmu] and the imperial family descends from Amaterasu (Brown, 2006: 59)" which gives understanding as to why Michinaga transplanted them in the mansion's garden for the imperial visit. "In fact, during the Heian period, the chrysanthemum evolved to be the prominent symbols of autumn, the season in which it blooms (Gunter, 2003: 28). 3) For the $k i$ [tree] category, there are depictions of the garden using the word tree and pine in the opening passage, in which autumn scene of Tsuchimikado Mansion's garden is described, the author mentions the trees beside the pond (123). While depicting the ritual of the Five Mystic Kings, she makes reference to the priests walking between the trees (124) while the grounds beneath the trees still covered in darkness (124). She mentions trees at two points during her narration of the ceremonies on the 5th day after the birth of the first prince: when she notes the nobles gathered under the trees (142) and the fire basket burning under the trees (142). She also depicts the wind in the pines that cover the islet in the middle of the lake at Tsuchimikado Mansion (158). A reference to pine appears in the depiction of the dancing and music aboard the dragon-form boats at the time of the imperial visit, in that the diarist recalls that the sound of the flutes and drums mingles with the matsu kaze [wind in the pines] (158). The pine was the main tree in shinden-zukuri gardens of Heian Period (Shirane, 2012: 137). 4) In the other category, there is a depiction of a tsuta [vine]. One night, reports Lady Murasaki, her majesty was testing the quality of the incense while waiting for the birth of the prince. Meanwhile, the ladies-in-waiting around her chatter about how unreasonably long it is taking for the vines to show their autumn colors. This small detail shows that in the Heian Period plants were a part of daily conversation (129).

Lady Murasaki's Own House: 1) There are no entries for the kusa category. There are some depictions of the garden of Lady Murasaki's house in the diary, in which there are two entries belonging to the hana and $k i$ categories recorded in the winter section of the diary: 2) The hana category entry is Lady Murasaki mentions "watching flowers listening to birds" (169) in that section of the diary where she expressed her feelings when she returned to her own house. 3) The ki category entry is a tree-reference that crops up when Lady Murasaki expresses her feelings while in her own house looking out at the trees in her garden (169).

\section{The Shinden-zukuri Mansion- The Buildings and Interior}

The buildings of shinden-zukuri mansions were made of hinoki wood. These buildings "had a central hall [shinden] to the north two flanking buildings and two open

\footnotetext{
${ }^{6}$ The scientific name of ominaeshi is Patrinia scabiosifolia. The term 'maiden flower' was used for ominaeshi by Bowring (Shikibu 1996 4), while in Turkish translation by Esen 'hanım çiçeği' [lady flower] (Shikibu 2009 4-5), because this flower is frequently associated with women and is used as a figure of speech indicating the woman addressed by the poet.
} 
corridors that extended south on both sides and were anchored by pavilions on the water". "The extensive use of verandas, open corridors, and open pillar construction allowed most of the interior spaces to open directly onto the garden" (Shirane, 2012: 90).

In the interior decoration seasons and the nature [plants] were represented abundantly. In the houses, flexible space dividers were used, (Coaldrake, 2002: 90) such as blinds which would have been made of bamboo, or the sliding screen paintings [fusuma-e] and screen paintings [byōbu-e] the nature [plants] were reflected indicating the seasons associated with them. Coaldrake, (2002: 90) states that these paintings "depicted themes from nature and showed the same concerns with the passage of human life mirroring the passing of the seasons". The mansion would have contained tatamis, mats made of rice straw, and small tables, boxes and lots of other things made from plants (Armstrong, 2001: 4-5, Esen, 2009 xxxvii-xliv, Goshima, 1998: 12-15, Shirane 2012: 89). With this point of view, the next point of inquiry was how plants reflect in the architecture of the buildings and interior decoration of the mansions. Items like blinds, which are mentioned many times, but since there is no overt mention of the plants it is made of, these items were not included in the analysis. The findings can be found below:

Tsuchimikado Mansion: 1) There is no mention belonging to the kusa category. 2) For the hana category, there is go table with kesoku [flower-shaped legs] (126) that Murasaki described, in the autumn section of the text. 3) For ki category, chin [aloes wood] appear in the text, as the material used to manufacture a tray and a table is described. These entries belongs to the autumn section of the diary, but not associated with seasons. Murasaki mentions a dais with a kuchigigata [decayed wood] pattern (149). This pattern, which certainly dates to the Heian Period, was frequently used on dais and kabeshiro, a curtain used in the Heian Period to separate rooms temporarily (O.K.J. 1988). This entry belongs to autumn section of the diary. Maki [Japanese cedar] is the old name of sugi which is mentioned only once in the text as the material of a door, in a poem addressed to Murasaki by Michinaga. One night, reports the diary, Murasaki hears someone tapping on her door, but she does not respond to it. Early the next morning she receives a poem from Michinaga saying that he tapped on her door made of maki [Japanese cedar] until the morning, just like a water rail (215). This entry has been recorded in the spring section of the text. Another entry is, while writing about the celebrations for the 7th day after the first prince's birth, mention is made of a willow box as material, which Murasaki saying that an imperial messenger presented to her majesty a yanagi-bako [willow box] containing a scroll list of the gifts (147). None of the above-mentioned entries is associated with seasons.

Palace: 1) There is no reference for kusa. 2) For hana: A reference is Murasaki's mention of an artificial mume [plum] branch that was sent to some Goseichi Dancers (175). Scholars have different opinions on what this branch actually signifies. Some of them take the word kokoroba to mean a head decoration, so that the reference here is to an artificial plum branch head decoration (shape); on the other hand, some think that Lady Murasaki had in mind boxes with artificial plum branches attached as decoration. The general consensus is that these branches were made of metal (Shikibu, 2008: 175, Shikibu, 2009: 89, KJN. 1998). The flower is associated 
with the beginning of the spring but this entry belongs to the end of winter section of the text. 3) For ki category reference to chin [aloes wood] appeared in the text, as the material used to manufacture a comb (183). This entry is in winter section of the text.

\subsection{Clothing}

The diary has a detailed description of clothing of ladies-in-waiting; all are related to the seasons and nature [plants]. These entries were analyzed as colors associated with plants, textile design and accessories represent plants.

\section{Clothing: Colors}

A plant-name stands for a "color", most of the time associated with seasons; this may be a kasane name, meaning the name of a color combination of a costume or it can be a word indicating the color of a textile. Shirane (2012: 58) calls this as 'wearing the seasons', this association of a layer colors or designs with seasons in the clothing of the Heian women. He argues that the waka had impact on women's fashion (Shirane 2012: 58-60): "The manner in which the seasonal associations of waka, particularly those of flowers and plants, permeated Heian aristocratic culture is perhaps most dramatically demonstrated in the design and colors of the women's [fashion] (Shirane 2012: 58):"

The costumes of the ladies-in-waiting of the diary is called ' 12 hitoe', which means that it comprised 12 layers of kimono and an unlined undergarment [hitoe]. The 12 layers of the attire were of different color combinations, depending on the season. (Noda, 2007: 227). Most of the color combinations are referred to in the diary using the name of a plant. "With only a few exceptions each color combination represented a specific season" (Shirane 2012: 60). In the diary the plants abundantly appears while describing the costumes of the ladies in waiting as seen below:

Tsuchimikado Mansion: 1) There are no entries for kusa category. 2) For hana category, kiku [chrysanthemums] (154, 155, 157), kuchinashi [gardenia] (155), hagi [Japanese-bush-clover] (128), shion [aster] $(128,155)$ and suō [sappan wood] (155, $156,163,187)$ are invoked as the colors of costumes worn in the autumn in the ceremonies of the birth of the first prince. 3) For ki category, the color of momiji [autumn-leaves] (155) is mentioned once in the text, and yanagi [willow] is used for the color of the costumes of the ladies-in-waiting, is in the part of the diary depicting the costumes on the day of the imperial visit (157). 4) ebi-zome [grape] (154, 155, 163) was the term used to describe the color of costumes, and it appears in the text in the section of the diary dealing with the festivities surrounding the first prince's birth. The color ebi-zome is attested in depictions of all four seasons.

Palace: 1) There are no entries for kusa category. 2) For hana category, in the course of the description of the ceremonies to mark the birth of the second prince, which are held in the spring, ume [plum] $(187,218,219,220)$, sakura [cherry] $(187,218$, $219,220)$ and yamabuki [Japanese rose] $(187,219)$ are invoked as the names of colors found on costumes associated with the spring. 3) For ki category yanagi [willow] is used for the color of the costumes of the ladies-in-waiting can be found in the description of the second prince's 50th day celebrations. This color is associated with the spring (219). 4) Ebi-zome [grape] $(179,187)$ as the color of costumes appears in 
the section of the diary dealing with the festivities surrounding the second prince's birth.

\section{Clothing: Textile Design}

Tsuchimikado Mansion: 1) Kusa is to conjure up a picture of a pattern in costumes. There are two entries of this type: Karakusa [Chinese vine] pattern (140) and aki no kusamura [autumn herb] pattern (140). The 'kara' of karakusa means 'T'ang China' and the pattern, originating in ancient Egypt and having come to Japan in the Asuka Period from T'ang China, represents the influence of the Silk Road in Japan (Fuchigami, 2001: 37). Aki no kusamura is a design associated with the autumn. 2) No entries for hana category. 3) The matsu-no-mi [pine cones] (140) and matsu-ga-e [pine branches] (145) which appear on the costumes of the ladies-in-waiting during the ceremonies to mark the birth of the first prince are associated with good fortune and longevity. Another wood design appears in the so-called komatsubara scene (144) meaning 'small pines field'. It is highly likely that this design was inspired by the congratulatory poem by Tsurayuki in the Gosenshū Anthology (poem number 1374), which includes the lines 'Ah Ōhara and Komatsubara at Oshio! May the trees soon grow tall and show us the face of immortality.' (Shikibu, 1996: 18).

\section{Clothing: Accessories}

Palace: For hana category, in one passage in the text, Murasaki refers to the artificial fuji [wisteria flowers] decorating the hair of an imperial messenger on the occasion of a special festival at the Kamo Shrines (183) in winter. The messenger in question is the fifth son of Michinaga, a member of Fujiwara clan. Wisteria is associated with the Fujiwara clan, because Fujiwara means 'Wisteria Field'. Wisteria is known as a springtime flower, but in the text it appears in 11th month (according to the lunar calendar). It can be presumed that the mention of wisteria is used to symbolize the Fujiwaras, as the messenger was a Fujiwara and his father Michinaga, the father of the empress, possessed notable power during this period.

\subsection{Literature}

\section{Literature: Poetry}

Shirane argues that Japanese poetry, in particular waka poetry the main literary form during the premodern period, is "one of the major reasons for prominence of nature and the four seasons in Japanese literary and visual culture" (Shirane 2012: 25). "Representation of nature in aristocratic visual culture -whether painting, poetry, or design- are thus seldom simply decorative or mimetic; they are almost always culturally and symbolically encoded" (Shirane 2012: 26).

In waka poetry the presence of nature references serves as a metaphor "to express emotions or thoughts through an item from the nature (Shirane 2012: 25)" but rarely reflects overt metaphors, "instead, the description of a flower, a plant, an animal, or a landscape became an implicit description of a human or internal state" (Shirane 2012: 26). Waka poetry also uses metonymy in the textual construction of landscapes, which help the poet to express a larger scene with few words (Shirane 2012: 26).

Waka in the diary has an outstanding place as do the other works of the Heian Period. In the diary, there are 18 waka poems and in 5 of them appear plants. 4 of 
these use plants to express emotions of thought:

Tsuchimikado Mansion: 1) For the kusa category, there is one entry. The ukikusa [duckweed] (214) appears in a song and represents the summer. It was used frequently in the poems of the Heian Period as a pun [kakekotoba] meaning 'floating kusa [duckweed]' and sadness, as the uki means both floating and sadness (O.K.J. 1988). 2) For hana category: In the poems Lady Murasaki exchanges with Michinaga, there are also metaphoric invocations of ominaeshi [maiden-flowers] (Ken, 2008: 32; 125). In this example, when Michinaga gives Lady Murasaki a sprig of maiden flowers and asks her for a waka poem, she is so ashamed of her morning face that, she speaks of the flower as if the flower were another woman, saying that the dew has shown favor on her, and that is why the flower looks so beautiful. In the second waka poem, Michinaga replies by saying that the flower's real beauty comes from the heart of the flower; that is, in this poem the maiden flower stands for Murasaki. This flower associated with autumn and takes place in the autumn section of the diary. Another poem alludes to the fact that, when the wife of the regent Michinaga sent Lady Murasaki a floss-silk damp with chrysanthemum dew [kiku no wata], Murasaki's poetic reply as a waka poem made mention of chrysanthemum dew, as well as wishing a thousand years of life upon the owner of the flower (129). This flower is associated with autumn and takes place in the autumn section of the diary. In another poem, attached to the fruit-bearing mume [plum] branch ${ }^{7}$ by Michinaga (214), a slightly sarcastic waka poem, addressed to Murasaki, where he says that she is a sukimono. Sukimono means both tart and amorous, and tartness here implies both Murasaki's character and the plum's taste. 3) For ki category: Matsu in a waka poem cited by Michinaga, addressed to his grandsons or young princes, where he comments "If there were no small pines [komatsu] in the fields" (217). This is a poem by Mibu no Tadamine, a poet of the Heian period. Through this quotation, Michinaga articulates his feelings towards the princes, calling them the fortune of his future. Pine in Japan represents longevity and immortality (Baird, 2001). According to Bowring (Shikibu, 1996: 18), "Komatsubara was an area just north-east of the capital, often used for its poetic associations."

\section{Literature: Prose Metaphors}

Palace: She was writing about the Empress' ladies-in-waiting. The place is not mentioned, but she speaks about the palace. So, I have added them to the palace title: 1) There is no entry for the kusa category 2) For hana category when she recalls contemplating flowers in the Highest Priest's place (198). 3) For ki category: There is an entry when Lady Murasaki speaks of herself as a mumoregi [withered-tree] (196), that is, as a person who has been deserted by the rest of the world. One is the utterance "Hana no tayori" (194), which means the message of the flowers and metaphorically refers to the seasons in which flowers bloom. 3) For ki category: Metaphorical reference to a tree is to a willow, which surfaces in a description of the character of Lady Koshōshō, one of the ladies-in-waiting at the court of the empress. Murasaki describes her as follows: "Lady Koshōshō is so indefinably elegant and graceful that she reminds one of a shidari-yanagi [weeping-willow] (189) in spring (Shikibu 1996 48)."

\footnotetext{
${ }^{7}$ Here it is referred to as a plum fruit.
} 


\begin{tabular}{|c|c|c|c|c|c|}
\hline & \multirow[b]{2}{*}{ Kusa 草/ Herb } & \multicolumn{2}{|c|}{ Hana 花/ Flower } & \multirow[b]{2}{*}{ Ki木/Tree } & \multirow[b]{2}{*}{ Other } \\
\hline & & Hana-Flower & $\begin{array}{c}\text { Ki no Hana- } \\
\text { Blossoms }\end{array}$ & & \\
\hline 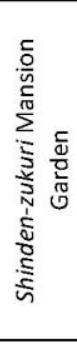 & $\begin{array}{l}\text {-Kusamura 草吉 } \\
ら: \text { Tuft of the } \\
\text { grass (1) } \\
\text { (Autumn/Tsuchi } \\
\text { mikado) }\end{array}$ & $\begin{array}{l}\text {-Hana 花: Flower (1) (Winter/ } \\
\text { Murasaki's house, no } \\
\text { association with seasons) } \\
\text { - Ominaeshi 女郎花 (1) } \\
\text { (Autumn/Tsuchimikado) } \\
\text { - Kiku 菊 (1) (Associated with } \\
\text { autumn but winter entry/ } \\
\text { Tsuchimikado) }\end{array}$ & & $\begin{array}{l}\text {-Ki 木: Tree (5) } \\
\text { (Autumn/ } \\
\text { Tsuchimikado) } \\
\text {-Ki 木: Tree (1) } \\
\text { (Winter entry/ } \\
\text { Murasaki's house, no } \\
\text { association with } \\
\text { seasons) } \\
\text {-Matsu 松: Pine (1) } \\
\text { (Tsuchimikado) }\end{array}$ & $\begin{array}{l}\text { - Tsuta 蔦 } \\
\text { Vine (1) } \\
\text { (Autumn/ } \\
\text { Tsuchimika } \\
\text { do) }\end{array}$ \\
\hline 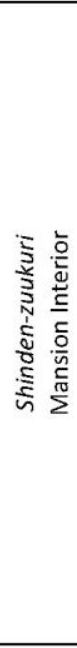 & & $\begin{array}{l}\text {-Hana 花: Flower (1) [Flower- } \\
\text { shaped-table-legs] } \\
\text { (no association with seasons- } \\
\text { Tsuchimikado) }\end{array}$ & $\begin{array}{l}\text {-Ume 梅: Plum } \\
\text { (1) (artificial- } \\
\text { shape) } \\
\text { (Palace) }\end{array}$ & $\begin{array}{l}\text { - Kuchigigata [decayed } \\
\text { wood] (dais' fabric } \\
\text { pattern } \\
\text { Tsuchimikado) } \\
\text { - Maki 槙:Japanese- } \\
\text { cedar (1) (door- } \\
\text { material- } \\
\text { Tsuchimikado) } \\
\text { - Chin 沈: Aloes-wood } \\
\text { (2) (table and tray } \\
\text { material, no } \\
\text { season/Tsuchimikado) } \\
\text { - Yanagi 柳: Willow (1) } \\
\text { (box- material } \\
\text { - Chin 沈: Aloes-wood } \\
\text { (1) comb- material } \\
\text { palace } \\
\text { (None associated with } \\
\text { seasons) }\end{array}$ & \\
\hline  & $\begin{array}{l}\text { Color: none } \\
\text { Pattern } \\
\text {-Karakusa 唐草: } \\
\text { Chinese-vine (1) } \\
\text {-Aki no } \\
\text { kusamura: } \\
\text { Autumn herbs (1) } \\
\text { (Autumn/ } \\
\text { Tsuchimikado) }\end{array}$ & $\begin{array}{l}\text { Color } \\
\text {-Yamabuki 山吹 (2) (Palace } \\
\text { assocciated with spring) } \\
\text {-Kiku菊 (6) } \\
\text {-Kuchinashi 㭽子 (1) } \\
\text {-Hagi 萩 (1) } \\
\text {-Shion 紫苑:Aster (2) } \\
\text { (All Tsuchimikado associated } \\
\text { with autumn) } \\
\text { Accessory } \\
\text {-Fuji 藤: Wisteria (1) (artificial- } \\
\text { shape) (No season/Palace) } \\
\end{array}$ & $\begin{array}{l}\text { Color } \\
\text {-Ume 梅 Plum } \\
\text { (6) } \\
\text {-Sakura 桜: } \\
\text { - Cherry (4) } \\
\text { (All of the above } \\
\text { associated with } \\
\text { spring, palace) } \\
\text {-Suō 蘇芳 (8) } \\
\text { (Autumn/ } \\
\text { Tsuchimikado) }\end{array}$ & $\begin{array}{l}\text { Color } \\
\text { - Momiji (1) autumn } \\
\text { leaves } \\
\text { - Yanagi 柳: Willow (4) } \\
\text { (associated with } \\
\text { spring, palace) } \\
\text { Pattern: } \\
\text { - Matsu 松: Pine (3) } \\
\text { (Tsuchimikado) }\end{array}$ & $\begin{array}{l}\text { Color } \\
\text { •Budō } \\
\text { 葡萄: } \\
\text { Grape (6) } \\
\text { (the color } \\
\text { associated } \\
\text { with four } \\
\text { seasons- } \\
\text { Tsuchimika } \\
\text { do) }\end{array}$ \\
\hline 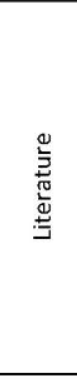 & $\begin{array}{l}\text {-Ukikusa 浮き草: } \\
\text { Duckweed (1) } \\
\text { (song) } \\
\text { (Tsuchimikado) }\end{array}$ & $\begin{array}{l}\text {-Hana (1) (waka) } \\
\text {-Ominaeshi 女郎花 (2) } \\
\text { (waka) (autumn/ } \\
\text { Tsuchimikado) } \\
\text {-Kiku 菊 (1) waka (associated } \\
\text { with autumn Tsuchimikado) } \\
\text {-Hana 花: Flower (2): } \\
\text { hana no tayori (metaphor- } \\
\text { spring), hana wo medzuru } \\
\text { (prose metaphor- spring) } \\
\text { Palace }\end{array}$ & & $\begin{array}{l}\text {-Ume 梅 Plum (1) } \\
\text { (waka) (spring/ } \\
\text { Tsuchimikado) } \\
\text { - Matsu 松: Pine (1) } \\
\text { (waka) (no } \\
\text { season/Tsuchimikado) } \\
\text {-Yanagi 柳: Willow (1) } \\
\text { (prose metaphor) } \\
\text {-Mumoregi (1) } \\
\text { (withered-tree) (prose } \\
\text { metaphor) } \\
\end{array}$ & \\
\hline 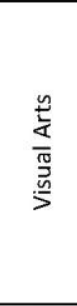 & & & & & $\begin{array}{l}\text {-Ashi 龩: } \\
\text { Reed (1) } \\
\text { (Calligraphy } \\
\text { letters } \\
\text { written in } \\
\text { the shape } \\
\text { of a } \\
\text { painting) } \\
\text { Palace }\end{array}$ \\
\hline Trad. & & -Kiku 菊: (1) & & & \\
\hline
\end{tabular}

Table 2 Forms of Secondary Nature in the Diary 


\subsection{Visual Art}

Although in the lives of aristocrats of the Heian Period visual arts such as screen paintings were abundantly seen, in the diary there is only one entry related to a visual art, calligraphy.

\section{Calligraphy}

Palace: Ashi [reed] manifests itself in the form of ashide [reed handwriting], an art-form from the Heian Period consisting of letters written in the shape of a painting representing reeds around water, together with rocks, grass and birds (KJN. 1998). In the text, a reference is made to a box with ashide calligraphy on it (183). This entry takes place in the winter section of the text.

\subsection{Traditions}

Tsuchimikado Mansion: For the hana category, Lady Murasaki mentions that she receives a kiku no wata [floss-silk soaked in chrysanthemum dew] (129) from the empress' mother on the 9th day of the 9th month, highlighting customary belief that chrysanthemums bring long life (KJN. 1998).

The findings presented in this section of the study are summarized in the Table 2.

\section{Conclusion}

The following results are gathered in this study.

- Firstly, a complete list of the plants appearing in the diary was made (please see appendix). Then, the Lady Murasaki's perception of plants was given particular attention to and a taxonomy method based on Murasaki Shikibu's own words was proposed, in which the plants were simply divided into basic categories. According to this taxonomy the plants appearing in the diary can be categorized under four main headings reflecting Murasaki's perception: 1) Kusa 草[Herbs or grass] 2) Hana 花 [Flowers], and 3) $K i$ 木 [Trees] and 4) Others (for this category there are three entries in which Lady Murasaki did not verbalize anything to reflect her perception of the category. A close look at her novel may change this fourth category).

- In the text, a total of 24 different terms have been used to refer to plants which appear 84 times in the text. 4 of them are general definitions, such as tree and grass or herbs, and these appear 16 times in the text. The other 20 are the names of specific plants. Of these, 2 are kusa [herb], 10 are hana [flowers], 5 are $k$ [ [tree] and 3 need to be placed under the heading "other". In total there are 68 references to all these different types of flora. The plants identified in the analysis are as follows:

Kusa 草(Herb): Karakusa 唐草 [Chinese-vine]; Ukikusa 浮き草 [Duckweed]

Hana 花 (Flowers): Fuji 藤 [Wisteria]; Ominaeshi 女郎花 [Maiden-flower]; Hagi 萩 [Japanese-bush-clover]; Shion 紫苑 [Aster]; Kiku 菊 [Chrysanthemum]; Kuchinashi 柅子 [Gardenia]; Yamabuki 山吹 [Japanese rose]; Ume 梅 [Plum]; Sakura 桜 [Cherry]; Suō 蘇芳 [Sappan-wood] 
Ki 木 (Tree, Tree-branch-fruit): Matsu 松 [Pine]; Chin 沈 [Aloes-wood]; Maki 槙 [Japanese cedar]; Yanagi 柳 [Willow]; Ume 梅 [Plum Tree]

Other: Tsuta 蔦 [Vine]; Ebi 葡萄 [Grape]; Ashi 葦 [Reed].

-The analysis of the text revealed that the nature represented in the diary of Lady Murasaki a work of classical Japanese literature is secondary nature and there is no single entry related to primary nature.

-Another noteworthy point is that the text suggests that Murasaki was been surrounded by plants in every sense, but she preferred to mention only some of them. This is another issue worth exploring. It can be suggested that her choice of mentioning some plants and not others is closely associated with her motives for recording (Esen 2012).

-The diary consists of 62 chapters (Shikibu 2009), with no mention of plants in 32 chapters. There are no plant-related references in the chapters depicting imperial births. Similarly, in the section focusing on the personalities and appearances of the ladies-in-waiting at the empress' court and on Murasaki's feelings, only 4 mentions are made of plants.

- Interestingly, the book contains no direct references to plants as food. The only partial exception is the mention of a rice-cake, but this has been excluded from this analysis since the word "rice" is not used in the text. In fact, the diary does not contain any descriptions of food whatsoever. Murasaki merely notes that "food is served". There is no mention either of the fragrance of plants or of the medicinal use of plants.

-8 of the 10 flower-references in the text do not actually pertain to real flowers. The only 2 that do are the references to ominaeshi [maiden flower] and kiku [chrysanthemum] in the section of the diary related to autumn. The absence of references to real flowers in the autumn-section of the diary is difficult to account for, but their absence in the spring-section may be related to the dates of the text entries for spring records, which are rather early for blossoms.

- 51 of the 84 references of plants in the diary are associated with concepts of time such as seasons, the age of a person or the passing of time. This applies to plants in all four headings: (Spring: Color name (157, 187, 218, 219, 220)/ literature (194); Autumn: Shinden-zukuri mansion's Garden (129)/ pattern (140)/ color name (128, 154, 155, 156, 157, 163, 187)/ traditional connotation (129); Four seasons: color name (154, $155,163,179,187)$; Passage of the time/ eternity: literature $(169,196,217) /$ textile design $(140,144,145)$.

-The references to plants are significantly linked to particular locations mentioned in the book. a) 12 of the 15 entries in the shinden-zukuri mansion are related to the garden category, pertaining to Tsuchimikado Mansion; of the other 3, one is a reference to the garden of Murasaki's house. Most of the entries for the shindenzukuri mansion building and interior belong to the Tsuchimikado Mansion, except 2 entries which are in the palace. b) The costume colors are connected with the Tsuchimikado Mansion and with the Palace, where as fabric designs are only 
described in the Tsuchimikado Mansion. c) All poems representing plants were recited in the Tsuchimikado Mansion. Prose metaphors are connected with the Palace related entries. The fact that most of the plant entries are linked to the Tsuchimikado mansion is worthy to note. The first reason for this is that in the diary the Tsuchimikado Mansion consumes a larger space than the other locations. We can assume that Lady Murasaki had more access to this location, beginning with the garden and other parts of the buildings in the Tsuchimikado Mansion compared to the Palace. So it can be suggested that Lady Murasaki had recorded what she actually saw around her (Esen 2012) and her motive of recording is determined by which of the plants she observed around and she reflected them in her diary.

-Focusing on which forms secondary nature appear in the text, the following results were reached: 1) Shinden-zukuri mansion a) garden which reflects real plants. b) shinden-zukuri mansion building and its interior reflects a) plants used as material b) and plants represented in the patterns of decorative items. It is worth to note that there is no entries related to visual arts such as screen paintings etc. 2) Costumes a) Color names b) Fabric design names c) Accessories 3) Literature a) Poetry b) Prose metaphors 4) Visual arts a) Calligraphy 5) Traditions

-It is noteworthy that some forms of the secondary nature that Murasaki had access, did not appear in the text. Again it can be suggested her motive for recording is the reason.

In conclusion, this study has looked at how nature is represented in a classical Japanese text, The Diary of Lady Murasaki, with an ecocritical perspective with respect to plants focusing on the subject with secondary nature phoneme. One of the major contributions intended in this study to the Japanese Studies field and to the studies on classical Japanese literature is the presentation of a complete list of all plants that appear in the diary; which is the first ever in the world including Japan. The second one is the taxonomy method suggested by using the own words of writer, which also enables the ability to include the entries not associated with seasons which will be benefit for the studies of plants in classical Japanese literature. It also aims to contribute to the ecocritism and secondary nature studies in the world by analyzing the diary of Lady Murasaki, and also contributed to ecocritism studies in Turkey dealing with a work of classical Japanese literature.

\section{REFERENCES}

ARIKAN, A. (2011). Edebi metin çözümlemesi ve ekoeleştiri. Mediterranean Journal of Humanities, 1(1), 41-49.

ARMSTRONG, P. (2001). "The Design of Nature in Heian Kyoto." Architectural Theory Review, 6:2. 1-11

ASQUITH, P. J.; Kalland, A. (eds.) (1997). Japanese Images of Nature: Cultural Perspectives. No. 1. USA. Taylor \& Francis. 
BAIRD, M. (2001). Symbols of Japan: Thematic Motifs in Art and Design. New York: Rizzoli.

BOWRING, R. (1996). "Introduction." The Diary of Lady Murasaki. New York: Penguin. BROWN, J. (2006). China, Japan, Korea: Culture and Customs. South Carolina: Book Surge.

COALDRAKE, W. H. (2002). Architecture and Authority in Japan. New York: Routledge.

ERGIN, M., Dolcerocca, O. N. (2016). Edebiyata Ekoeleştirel yaklaşimlar: Ekoşiir ve Elif Sofya. Selçuk Üniversitesi Edebiyat Fakültesi Dergisi (SEFAD), (36), 297-314.

ESEN, E. (2012). Murasaki Shikibu'nun Günlüğünde 'Gerçeği Kaydetme' Çabası ve Yöntemi. Türkiye'de Japonya Çalışmaları. (Eds.) S. Esenbel, E. Küçükyalçın. Istanbul: Boğaziçi Üniversitesi Yayınevi.

ESEN, E. (2009). Murasaki Shikibu ve Heian Dönemi. Murasaki Shikibu'nun Günlüğü. İstanbul: İş Kültür Yayınları.

FUCHIGAMI, K. (2001): Analysis of the Spiral Pattern Karakusa. Journal for Geometry and Graphics 5-1, 35-43.

FUJIMOTO, K. (1971). Rokujo-in Shiki no Machi no Dōshokubutsu Settei wo Megutte. Kikan Bungaku Gogaku 61, 109-120.

GLOTFELTY, C., and Fromm, H. (Eds.). (1996). The Ecocriticism Reader: Landmarks in Literary Ecology. USA. University of Georgia Press.

GOSHIMA, K. (1998). Genji Monogatari Rokujōin no Seikatsu. Japan: Fuzoku Hakubutsukan.

GUNTER, S. E. (2003). Japanese Design Motifs and Their Symbolism as Used on Itajime-Dyed Juban. Master Thesis. Georgia: University of Georgia.

HEISE, U. K. (2006). The Hitchhiker's Guide to Ecocriticism. PMLA, 121(2), 503-516.

HIROE, M. (1969). Genji Monogatari no Shokubutsu. Koten Shokubutsu Zenshu 5, Japan: Ariake Shobo.

HIROE, M. (1981). Heian Sono, Taketori Monogatari, Ise Monogatari, Kokin Wakashu, Makura no Shoshi, Genji Monogatari no Kusaki. Japan: Heian Jingu.

HIROKAWA, K. (1978). Genji Monogatari no Shokubutsu Vol. 84 Japan: Kasamashoin.

INAGA, K. (1971). Murasaki Shikibi Nikki no Itsubun Shiryō Saemon no Naishi' no 'ume no hana' no uta Nikki no Seirtisu to Seikaku wo Meguru Okusetsu. Kokugo to Kokubungaku 48-4, 55-65.

KATŌ, S. (2011). ni Saguru Azuma-Kuni no Rekishi (Kankyō to iu Shiza - Nihon Bungaku to Ekokrichizumu). Ajia Yugaku, (143), 185-192.

KAWAHARA, T. (1987). Heian Jidai no Nikki Bungaku ni Miru Koen Hiyōsha. Journal of the Japanese Institute of Landscape Architects 50-5, 1-6.

KEENE, D. (1999). Seeds in the Heart. New York: Columbia University.

KEN, A. (2008). Murasaki Shikibu Nikki Kenkyū. Tokyo: Shintensha. 
KOGA, M. (1971). Genji Monogatari no Shokubutsu. Japan: Ōbūsha.

MASAMI, Y. (2017). On Harmony with Nature: Toward Japanese Ecocritisim. Ecocriticism in Japan. (eds.) H. Wake, K. Suga, Y.Masami. London: Lexington Books

MATSUDA, O. (1980). Koten Shokubutsu Jiten. Japan: Kodansha.

NIWA, T., Muramoto, S. (1937). Mume Metsugi Hanshoku no Shinhō. Journal of the Japanese Institute of Landscape Architects 4-1, 44-56a.

NODA, Y. (2007). Heian Izoku Shakai ni okeru Kasane no Irome. Ochanomizu Daigaku :227 -232.

NODA K. (2011). Niji-shizen to Nosei no Shizen (Kankyō to iu Shiza - Nihon Bungaku to Ekokrichizumu). Ajia Yugaku, (143), 34-36.

ŌNUKI, S. (1986). Hana no Genji Monogatari. Japan: Gurafikkusha.

RHINE, M. E. (2017). A Path Toward Paraxis Inspired by Ecocritical Reading of the Tale of Genji and a Japanese Folk Tale. Ecocriticism in Japan. (eds.) H. Wake, K. Suga, Y.Masami. London: Lexington Books

SHIKIBU, M. (1970). Murasaki Nikki-Kurokawabon. Japan: Kasama-shoten, 1970.

SHIKIBU, M. (1996). The Diary of Lady Murasaki. Trans. R. Bowring. New York: Penguin Classics, 1996.

SHIKIBU, M. (2008). Murasaki Shikibu Nikki. Izumi Shikibu Nikki, Murasaki Shikibu Nikki, Sarashina Nikki. Tokyo: Shōgakukan.

SHIKIBU, M. (2009). Murasaki Shikibu'nun Günlüğü. Trans. E. Esen. Istanbul: İş Kültür Yayınları.

SHIRANE, H. (2012). Japan and the Culture of the Four Seasons: Nature, Literature, and the Arts. USA: Columbia University Press.

SAZYEK, H., Sürücü Y. (2018). Cahit Külebi'nin Şiirlerine Ekoeleştiri Çerçevesinden Bakmak. Kocaeli Üniversitesi Sosyal Bilimler Dergisi 36: 25-38.

TAKEUCHI, H. (1983). 'Murasaki Shikibu Nikki'Ron- Murasaki Shikibu to Fujiwara Michinaga to no aida ni okeru 'Ominaeshi' 'Shira Tsuyu wa' no Zōtōka ni kanshite. Nihon Bungaku Kenkyū 22, 144-151.

TOYAMA, E. (1927). Genji Monogatari to Nihon no Teien. Japan: Bunyūsha.

TSUDA, N. (2009). History of Japanese Art: From Prehistory to the Taisho Period. Tokyo: Tuttle Publishing.

WAKE, H. Suga, K.; Masami, Y. (eds) (2017).. Ecocriticism in Japan. London: Lexington Books

ZAPF, H. (Ed.). (2016). Handbook of Ecocriticism and Cultural Ecology (Vol. 2). Germany: Walter de Gruyter.

(KJN), Shinmura, I. (1998). Kojien. (5th edition). Japan: Iwanami Shoten.

(O.K.J.) (1988). Obunsha Kogo Jiten. Japan: Obuncsha. 
Appendix 1 :Analysis (with Glosses) ${ }^{8}$. of Plants in MSN in their Order of Appearance $^{9}$

\section{1st Volume}

\section{i. Autumn in Tsuchimikado}

(TSUCHIMIKADO MANSION- AUTUMN $\downarrow$ )

1) Ike no watari no kozue-domo 木寸总とも(梢ども)... (Shikibu, 2008:123)

Pond GEN. side GEN. tree-top PL.

2) ....yarimizu no hotori no kusamura 草むら, (Shikibu, 2008:123)

ditch GEN. side GEN. grass-tuft

\section{ii. The Ritual of the Five Great Mystic Kings}

3) Mada yofukaki hodo no tsuki sashi-kumori, konoshita 木のした wo guraki ni, (Shikibu, 2008:124)

still midnight around GEN. moon get-cloudy under-tree ACC. darken PT.

4) ...karahashi-domo wo wataritsutsu, ko no ma木のま wo wakete kaeri iru hodo mo, (Shikibu, 2008:124)

Chinese-bridge PL. ACC. pass PROG. tree GEN. between ACC. open CON. come-back PROG. around too

\section{iii. Maiden Flower in the Morning Mist}

5) Hashi no minami naru ominaeshi みなへし no imijiu sakari naru wo, (Shikibu, 2008:125)

bridge GEN. south be maiden-flower GEN. excessively prime COP. ACC.

6) ....hito-eda 一枝 orase-tamaite... (Shikibu, 2008:125)

one-sprig break RES. CON.

7) Ominaeshi みなへし sakari no iro wo miru karani... (Shikibu, 2008:125)

maiden-flower prime GEN. color ACC. see only

8) Shira-tsuyu wa wakite moｏkaji ominaeshiをみなへし... (Shikibu, 2008:125)

white dew PT. seperate CON. even put NEG. maiden-flower

iv. Regent Michinaga's Son Yorimichi: No plants in this chapter.

\footnotetext{
${ }^{8}$ Gloss Abbreviations: ACC. accusative; CAU. causative; COND. Conditional; CJ. conjecture (suiryō); CON. conjunction; COP. copula; EMP. emphatic particle; GEN. genitive; LOC. locative case; NEG. negative; NPST. non-past; PAS. passive; PST. past; PLN. plain form; PL. plural; POL. polite language (Teineigo); PROG. progressive-continuative; PT. particle; RK. attributive form (Rentai-kel); RYK. compound form (renyōkei); RES. respectful language (sonkeigo); SHK. terminal form (shūshi-kel); SJ. subjunctive mood; TOP. topic; Q. interrogative particle (marker). Bold letters indicate plant name and underlined letters indicate the data enlighten the use of plants. Volumes and sessions are derived from Turkish (Shikibu 2009) and modern Japanese (Shikibu 2008) translations.

${ }^{9}$ Only plants that are explicitly mentioned in the diary have been considered.
} 


\section{v. Banquet of Governor of Harima as a Forfeit for Losing at Go}

9) kesoku けそく nado yue-yueshiku shite, (Shikibu, 2008:126) flower-shaped-table-legs etc. refined do CON.

vi. After 20th of 8th Month, The Night Duty: No plants in this chapter. vii. 26th of 8th Month, Sleeping Face of Saishō no Kimi 10) ...hirune shi tamaeru hodo nari keri. Hagi はき, shion, iro-iro no kinu ni, (Shikibu, 2008:128) nap do POL. about COP. PST. Japanese-bush-clover aster various GEN. silk PT.

11) ...hirune shi tamaeru hodo nari keri. Hagi, shion しほん, iro-iro no kinu ni, (Shikibu, 2008:128)

nap do POL. about COP. PST. Japanese-bush-clover aster various GEN. silk PT. viii. 9th of 9th Month, Floss-silk Damp with Chrysanthemum Dew 12) Kokonu-ka, kiku no wataきくのわた wo Hyōbu-no-Omoto no motekite (Shikibu, 2008:129)

9th(day) chrysanthemum GEN. cotton ACC. Hyōbu-no-Omoto GEN. bring-come CON. 13) Kiku no tsuyu きくの露 wakayu bakari ni sode furete... (Shikibu, 2008:129) chrysanthemum GEN. dew rejuvenate for sleeve touch CON. 14) hana 花 no aruji ni chiyo wa yudzuramu (Shikibu, 2008:129) flower GEN. (land-lady) to thousand-years TOP.PT. (stay) SJ.

ix. . Evening of 9th of 9th Month, The Test of the Incense by Her Majesty 15) ...tsuta つた no irono kokoro-motonaki nado, kuchi-guchi kikoyesasuru ni, (Shikibu, 2008:129) vine GEN. color GEN. irritation-of-waiting-long etc.from-mouth-to-mouth hear RES. PT.

x. 10th of 9th Month, The Birth Room for Empress: No plants in this chapter.

xi. 11th of 9th Month Dawn; Kaji Ceremony: No plants in this chapter.

xii. Her Majesty's Safe Delivery: No plants in this chapter.

xiii. Joy and Relief for Her Majesty's Safe Delivery: No plants in this chapter. xiv. Ceremonial Sword from the Palace: No plants in this chapter. xv. The Ceremonial First Bathing

16) Karaginu ha matsu no mi まつのみ no mon... (Shikibu, 2008:140) (kimono-jacket) PT. pine GEN. cone GEN. pattern 17) Koshi wa usumono, karakusa からくさ o nuitari. (Shikibu, 2008:140) waistband TOP.PT. gauze chinese-vine ACC. sew PROG. 
18) Shōshō no Kimi wa, aki no kusamura 秋の草むら, chō, tori nado wo... (Shikibu, 2008:140)

Shōshō no Kimi TOP.PT. autumn GEN. herb-tuft. butterfly bird etc. ACC.

xvi. 12th of 9th Month, Costumes of The Ladies in Waiting: No plants in this chapter.

xvii. 13th of 9th Month, Celebrations on the 3rd Day of The Imperial Birth

19) ...chin ちん no kakeban, shirogane no ō-sara nado, kuwashiku wa mizu. (Shikibu, 2008:141)

aloes-wood GEN. end-table silver GEN. HON. plate etc. detailed TOP.PT. see NEG.

xviii. 15th of 9th Month, Celebrations on the 5th Day of The Imperial Birth

20) kagaribi-domo wo ko no shita 木のした ni tomoshi tsutsu... (Shikibu, 2008:142)

fire-basket PL. ACC. tree GEN. below PT. light PROG.

21) ko no moto 木のもと goto ni, uchi-murete oru Kandachime no zuijin nado... (Shikibu, 2008:142)

tree GEN. under PT. every gather CON. RES. noble GEN. retainer etc.

22) Oshio-yama no komatsubara こ松原 wo nuitaru sama, ito okashi. (Shikibu, 2008:144)

Oshio Mountain GEN. Komatsubara (young-pine-field) ACC. embroider PROG. appeareance very rare

23) Mo no nuimono mo, matsu ga e 松か枝 no yowai o arawasowasetaru... (Shikibu, 2008:145)

train GEN. embroidery also pine(GEN.) branch PT. GEN. (longevitiy) ACC. express PAS. PROG.

xix. 16th of 9th Month, Young Ladies in Waiting in the Boat No plants in this chapter.

xx. 17th of 9th Month, Celebrations on the 7th Day of The Imperial Birth

24) mono no kazu-kazu kakitaru fumi, yanagi-bakoやなきはこ ni irete maireri. (Shikibu, 2008:147)

thing GEN. many written writing willow box in put CON. RES.

xxi. 19th of 9th Month, Celebrations on the 9th Day of The Imperial Birth

25) Koyoi wa, omote kuchigi-gata くちきかた no kichō, rei no sama nite,... (Shikibu, 2008:149)

this-night TOP. PT. front decayed-tree GEN. (curtain-screen) usual (way) COP. CON. xxii. Michinaga Holds His Grandson, No plants in this chapter. (TSUCHIMIKADO MANSION- WINTER $\downarrow$ ) 


\section{xxiii. Emperor's Visit to the Tsuchimikado Mansion Approaches}

26) Yo ni omoshiroki kiku no ne 菊のね wo tadzune tsutsu horite mairu.... (Shikibu, 2008:150)

really (rare) chrysentamum GEN.root ACC. (order) PROG. dig CON. RES.

xxiv. Exchange of Letters with Lady Koshōshō in Rainy Days: No plants in this chapter.

xxv. 16th of 10th Month, Emperor's Visit to the Tsuchimikado Mansion:

27) Uwagi kiku菊

no itsu-e,... (Shikibu, 2008:154)

(kimono-jacket) chrysentamum GEN. five-layer

28) Kurenai ni ebi-zome 总ひそめ no orimono no uchiki, (Shikibu, 2008:154)

crimson PT. grape-color GEN. (damask) GEN. uchiki-gown

xxvi. Costumes of the Ladies in Waiting on the day of Imperial Visit

29) ...uwagi wa, oshi-watashite suōすはう no orimono nari. (Shikibu, 2008:155)

(kimono-jacket) (all same) CON. sappan-wood GEN.(damask) COP.

30) Tada Mumo no Chūjō zo ebi-zome 总ひそめ wo kite haberi shi. (Shikibu, 2008:155)

only Mumo no Chūjō EMP. grape-color

ACC. wear POL. PST.

31) Uchimono-domo wa, koki usuki momiji 紅葉 wo koki-maze taru yō nite, (Shikibu, 2008:155)

beaten-silk PL.TOP.PT. dark light autumn-leaves ACC. stir PROG. like CON.

32) ...naka naru kinu-domo, rei no kuchinashi くちなし no koki usuki... (Shikibu, 2008:155)

inside be silk PL. regular GEN. gardenia GEN. dark light

33) ...shion しをん iro, (Shikibu, 2008:155)

aster color

34) ...ura aoki kiku あをき菊 wo, moshiwa mi-e nado, kokoro-gokoro nari. (Shikibu, 2008:155)

back blue-chrysentamum ACC. or three layer etc. (different) be

35) moshiwa suō すわう nado, (Shikibu, 2008:155)

or sappan-wood etc.

36) Uchiki wa kiku きく no mi-e itsu-e nite, (Shikibu, 2008:155)

uchiki-gown TOP.PT. chrysantemum three-layer five-layer COP.CON.

37) ...kiku 菊 no itsu-e no karaginu wo kokoro-gokoro ni shitari. (Shikibu, 2008:155)

chrysantemum GEN. five-layer GEN. (kimono-jacket) ACC. (different) do 
38) ....ue wo ba suō すはう... (Shikibu, 2008:155)

to ACC. sappan-wood

39) Ue usu- suōうす〉はう, (Shikibu, 2008:156)

top light sappan-wood

40) ... tsugi-tsugi koki suōすはう, (Shikibu, 2008:156)

one-after-the-other dark sappan-wood

41) Sakyō wa ao-iro ni yanagi あを色にやなき no mumon no karaginu... (Shikibu, 2008:157)

Sakyō TOP.PT. blue-color PT. willow GEN. paternles GEN. (kimono-jacket)

42) ...Chikuzen wa kikuきく no itsu-e no karaginu, (Shikibu, 2008:157)

Chikuzen TOP.PT. chrysantemum GEN. five-layer GEN. (kimono-jacket)

43) ....karaaya no ki naru kiku きなる菊 no uchiki zo, (Shikibu, 2008:157)

Chinese brocade GEN. yellow become chrysantemum GEN.uchiki-gown EMP.

xxvii. Music and Dance Performance in the Presence of the Emperor

44) ... tsudzumi no oto mo, matsukaze 松風 mo, (Shikibu, 2008:158)

shoulder-drum GEN. sound too pine-wind (oto) too

45) kobukakuこふかく fuki-awase te, ito omoshiroshi... (Shikibu, 2008:158)

deep in the woodsGEN. blow CON. very interesting

xxiii. 17th of 10th Month at the Presence of Her Majesty: No plants in this chapter.

xxix. The Moon and the Masters of the Households: No plants in this chapter.

xxx. 1st of the 11th Month, Celebrations on the 50th Day of The Imperial Birth

46) ... Ō-Miya no o-mono, rei no chin no oshiki, (Shikibu, 2008:162)

(Her-Majesty) GEN. HON.thing usual GEN. aloes-wood GEN. tray-with-legs

47) ... Ō-Miya wa ebi-zome 总ひそめ no itsu-e no ō zo, (Shikibu, 2008:163)

(Her-Majesty) TOP.PT. grape-color GEN. five layer GEN. HON. gown

48) ... suōすおう no ō-ko-uchiki tatematsureri. (Shikibu, 2008:163)

sappan-wood GEN. HON. ko-uchiki gown RES.

xxxi. The Carouse after the Celebrations on the 50th Day of The Imperial Birth: No plants in this chapter.

xxxii. The Preparations to Return to the Palace: No plants in this chapter. 
xxxiii. When I am Back to My Home

(MURASAKI'S HOUSE- WINTER $\downarrow$ )

49) Midokoro mo naki furusato no kodachi 木たち wo miru... (Shikibu, 2008:169)

worth-to-see even NEG. home PT. GEN. grove ACC. see

50) ...hana tori 花鳥 no iro wo mo ne wo mo, (Shikibu, 2008:169)

flower(s) (and) bird(s) GEN. color ACC. also voice ACC. also

xxxv. 17th of 11th month, Return to the Palace: No plants in this chapter. (PALACE- WINTER $\downarrow$ )

xxxvi. The day after the Return to the Palace: No plants in this chapter.

xxxvii. 20th of the 11th Month, Gosechi Spectacle for the Empress

51) hako hito-yorohi ni takimono irete, kokoroba, mume no eda 梅枝 wo shite, (Shikibu, 2008:175)

box one-pair PT. incence put CON. (artificial-flower) plum GEN. sprig ACC. do CON.

xxxviii. 21st of the 11th month, Gosechi Spectacle for the Emperor No plants in this chapter.

xxxix. 22nd of the 11th month, Gosechi Girls at the Presence of The Emperor

52) Owari wa tada ebi-zome 总ひそめ wo kisetari. (Shikibu, 2008:179)

Owari TOP.PT. only grape-color ACC. wear PAS.

xl. 23rd Toyonoakari Festival: No plants in this chapter.

xli. The Lonely Days after the Gosechi Festivities: No plants in this chapter.

xlii. 28th of 11 month Kamo Shrine Festivities

53) Kagami oshi-irete, chin no kushi ちんのくし shirogane no kōgai nado, (Shikibu, 2008:183)

miror put CON. aloes-wood comb silver GEN. pattern etc.

54) Hako no futa ni ashide あして ～ni uki-ide taru wa... (Shikibu, 2008:183)

box GEN. lid PT.( reed-like-script)PT. (emboss) PROG. TOP.PT.

55) Tsukai-no-Kimi no fuji 藤 kazashite... (Shikibu, 2008:183)

(Messenger) GEN. (artificial) wisteria (put in the hair)CON.

xliii. 29th of 12th Month, Back to the Palace: No plants in this chapter.

xliv. 30th 29th of 12th Month, Tsuina Ceremony, No plants in this chapter.

xIv. 3rd of the New Year, Rice-Cake Ceremony ((PALACE-SPRING $\downarrow$ )

56) tsuitachi no hi wa kurenai, ebi-zome 总ひそめ, (Shikibu, 2008:187)

first-day GEN. day TOP.PT. crimson, grape-color 
57) Futsuka, kōbai こうはい no orimono, (Shikibu, 2008:187)

Second-day red-plum-blossom (color) GEN. (damask)

58) ...Mika wa, karaaya no sakura $さ く ら$ gasane, (Shikibu, 2008:187)

Third-day TOP.PT. Chinese brocade GEN. cherry (color) layers

59) .... karaginu wa suōすわう no orimono, (Shikibu, 2008:187)

(kimono-jacket) TOP.PT. sappan-wood (damask)

60) ... Moyegi, suōすはう, (Shikibu, 2008:187)

green, sappan-wood

61) ... yamabuki 山吹 no koki usuki, (Shikibu, 2008:187)

Japanese-rose GEN. dark light

62) ... kōbai こうはい, usu-iro nado (Shikibu, 2008:187)

red-plum-blossom (color) light-color etc.

63) ... ebi-zome 总ひそめ no ukimon no ... (Shikibu, 2008:187)

grape-color GEN. uki-baracode GEN.

\section{2ndVolume}

xIvi. Lady Saishō, Lady Koshōshō, Lady Miya no Naishi, Lady Shikibu

64) Kisaragi bakari no shidari-yanagi したり柳 no sama shitari. (Shikibu, 2008:189) (second month of lunar calendar) about GEN. weeping-willow GEN. appearance do xlvii. Ladies in waiting: Kodayū , Genshikibu, Kohyōe, Shōni, Miyagi-no-jiju, Gosechi-no-ben, Komuma: No plants in this chapter.

xIviii. About Priestess of Kamo Shrine

65) ...hana no tayori 花のたより hototogisu no tadzune-dokoro ni mairitareba, (Shikibu, 2008:194)

flower-season lesser-cockoo GEN. visit place to go RES. COND.

66) Kō ito mumoregi むもれ木 wo ori iretaru kokorobase nite, (Shikibu, 2008:196)

like-this very bog-wood -e ACC. (inserted) feeling COP.CON.

xlix. Her Majesty's Subordinates

67) Saiin nado yō no tokoro nite, tsuki wo mo mi, hana 花 wo mo medzuru, (Shikibu, 2008:198)

Saiin etc. like GEN. placeCOP.CON. moon ACC. too see flower ACC. too admire I. Izumi Shikibu, Akazome Emon, Sei Shōnagon: No plants in this chapter. 
li. Voice of My Heart: No plants in this chapter.

lii. Shape of My Heart: No plants in this chapter.

liii. Shape of The Others Hearts: No plants in this chapter.

liv. A nick name 'Lady Chronicle': No plants in this chapter.

Iv. The desire of dedicating myself into the Religion and Some Doubts: No plants in this chapter.

Ivi. About being Lady in Waiting in the Court: No plants in this chapter.

\section{3rd Volume}

Ivii. About Tsuchimikado Mansion:

(TSUCHIMIKADO MANSION $\downarrow$ )

68) "Ike no ukikusa うき草" to utaite, (Shikibu, 2008:214)

pond GEN. duckweed as sing CON.

Iviii. About the Genji Monogatari

69) ...mume むめ no shita ni shikaretaru kami ni kakasetamaeru. (Shikibu, 2008:214)

plum GEN. under to (lay) PAS. PROG. paper in write RES.

lix. About the Night in the Corridor

70) ...maki まき no toguchi ni tataki wabitsuru. (Shikibu, 2008:215)

Japanese-cedar GEN. door-way at knock (grive) SH.RK.

Ix. First 3 days of New Year, Rice Cake Ceremony for The Princes: No plants in this chapter. (PALACE)

Ixi. 2nd Day of the New Year: First Child Day (TSUCHIMIKADO MANSIONWINTER $\downarrow$ )

71) Nobe ni komatsu 小松 no nakariseba (Shikibu, 2008:217)

(fields-arround) LOC. young-pine GEN. be NEG. COND.

Ixii 15th of the New Year, 50th Day Ceremonies For Prince Atsukasa

72) ...sakura 桜 no orimono no uchiki, (Shikibu, 2008:218)

cherry (color) GEN. (damask) GEN. uchiki-gown

73) ...Kōbai こうはい ni moyegi, (Shikibu, 2008:219)

red-plum-blossom (color) PT. green

74) ... yanagi やなき no karaginu, (Shikibu, 2008:219)

willow GEN. (kimono-jacket) 
75) ...kōbai こうはい, moegi, (Shikibu, 2008:219)

red-plum-blossom (color) green

76) ... yanagi やなき, yamabuki no ō-zo, (Shikibu, 2008:219)

willow Japanese-rose GEN imperial garments

77) ... yanagi, yamabuki 山ぶき no ō-zo, (Shikibu, 2008:219)

willow Japanese-rose GEN imperial garments

78) ... ue ni wa ebi-zome 总ひそめ no orimono (Shikibu, 2008:219)

top PT. grape-color GEN. (damask)

79) ... yanagi やなき no uejiro

no ō-ko-uchiki, (Shikibu, 2008:219)

willow GEN. (white-front-layer) GEN. HON. ko-uchiki gown

80) Ebi-zome 总ひそめ no orimono no ko-uchiki(Shikibu, 2008:219)

grape-color GEN. . (damask) GEN. ko-uchiki gown

81) ...sakura さくら no karaginu kitari. (Shikibu, 2008:219)

cherry (color) GEN. (kimono-jacket) wear PROG.

82) ... ue ni kōbai こうはい no koki usuki itsutsu wo kasane tari. (Shikibu, 2008:220)

top PT.red-plum-blossom (color) GEN. dark light five ACC. laye PROG.

83) Karaginu, Sakura さくら. (Shikibu, 2008:220)

(kimono-jacket) cherry (color)

84) Gen-Shikibu wa koki ni, mata kōbai こうはい no aya zo kite haberu meri shi.

(Shikibu, 2008:220)

Gen-Shikibu. TOP.PT. dark PT. again red-plum-blossom (color) brocade EMP. wear POL. CJ. PST. 